\title{
Antitumor Activity of New Antitumor Substance, Polyoxomolybdate, against Several Human Cancers in Athymic Nude Mice
}

\author{
Haruhisa Fujita, Tomonobu Fujita, Toshiharu \\ Sakurai, Toshiniro Yamase* and Yoshiko Seto \\ Division of Chemotherapy, Pharmaceutical Institute, School \\ of Medicine, Keio University, Tokyo 160, and *Research \\ Laboratory of Resources Utilization, Tokyo Institute of \\ Technology, Yokohama 227
}

\begin{abstract}
Fujita, H., Fujita, T., Sakurai, T., Yamase, T. and Seto, Y. Antitumor Activity of New Antitumor Substance, Polyoxomolybdate, against Several Human Cancers in Athymic Nude Mice. Tohoku J. Exp. Med., 1992, 168 (2), 421-426 - Antitumor polyoxomolybdates have been recognized in the course of study on the medical utilization of polyoxometalates, inorganic polymers of metal oxide. $\left[\mathrm{NH}_{3} \mathrm{Pri}\right]_{6}\left[\mathrm{Mo}_{7} \mathrm{O}_{24}\right] \cdot 3 \mathrm{H}_{2} \mathrm{O}$ (PM-8) was found as a representative of antitumor polyoxomolybdates. The growth suppressions of PM-8 against Co-4 human colon cancer xenografted under the subrenal capsule in cd-1 mice were equal or superior to that of 5-FU, MMC, ACNU, ADM and CDDP. Potent antitumor activity of PM-8 is also established against MX-1 human breast and OAT human lung cancer xenografted in athymic nude mice. Polyoxomolybdate is a new type of antitumor substance. - antitumor effect; polyoxomolybdate; human tumor; xenograft; nude mouse
\end{abstract}

The use of cis-diamminedichloroplatinum (CDDP) has been now been proved to be significant in treating mouse tumors and several human tumors, particularly the seminomas (Rosenberg et al. 1969). Dramatic improvement have been made in the treatment of patients with disseminated testicular tumors by modern chemotherapeutic protocols, which are based on the dose-dependent antitumor activity of CDDP (Samson et al. 1984). However, the excellent antitumor activity of CDDP is accompanied with strong toxic effects. From chemical analogy with CDDP, the antitumor active compounds such as titanocene dichloride and copper (I), silver (I), and gole (I or III) tetrahedral diphosphine comlexes have been investigated (Harstrick et al. 1983). In addition, organosilicone compounds of other organometallic complexs with favorable antitumor properties, such as trimethylsilylethylthioethylamine and its derivatives, have been found (Toyoshima et al. 1985 ; Fujita et al. 1990, Sakurai 1990). In the course of our examination of biological effects of polyoxometalates, inorganic polymers of metal

Address for reprints : 35 Shinanomachi, Shinjyuku-ku, Tokyo 160, Japan. 
oxide, significant antitumor effect of polyoxomolybdates was found against conventional murine tumors (Yamase et al. 1988). This paper describes additional potent activities of the polymolybdates against human cancer xenografts, as a way of realizing the chemical usage of these substances.

\section{Materials and Methods}

Three human tumors were used throughout this study ; Co-4 colon cancer, MX-1 breast cancer and OAT lung cancer. We used Balb/c athymic nude mice for antitumor evaluation by implantation method and female cd-1 mice for subrenal capsule assay (SRC assay).

\section{RESULTS}

\section{Antitumor evaluation against Co-4 by SRC assay}

From the screening of fifty polyoxometalates for antitumor activities using SRC assay, antitumor activities were found for four polyoxomolybdates of PM-8, 17, 26 and 32. The activities of the polyoxomolybdates were compared with those of the reference antitumor drugs in Table 1. Both PM-8 and PM-17 showed significant activities, however, the latter exhibited a strong toxicity as represented by a severe body weight loss in the mice.

\section{Antitumor activities of $P M-8$ against $M X-1$ and $O A T$ by SRC assay}

The activities of PM-8 against MX-1 and OAT were compared with those of

TABLE 1. Antitumor activity of polyoxometalates against Co-4 human cancer xenograft under the subrenal capsule in mice ${ }^{1}$

\begin{tabular}{lcccc}
\hline \multicolumn{1}{c}{ Compound $^{2}$} & $\begin{array}{c}\text { Dose } \\
(\mathrm{mg} / \mathrm{kg})\end{array}$ & $\begin{array}{c}\text { Treatment } \\
\text { schedule }\end{array}$ & $\begin{array}{c}\text { Relative body weight } \\
\text { (day 6/day 0) }\end{array}$ & $\begin{array}{c}\text { Relative tumor size } \\
\text { (day 6/day 0) }\end{array}$ \\
\hline Tumor control & Vehicle & day 1-day 5 (i.p.) & $1.03 \pm 0.01^{3}$ & $1.51 \pm 0.11(-)^{4}$ \\
PM-8 & 200 & day 1-day 5 (i.p.) & $1.07 \pm 0.01$ & $0.67 \pm 0.09(54.3)^{\mathrm{c}}$ \\
PM-17 & 25 & day 1-day 5 (i.p.) & $0.70 \pm 0.05$ & $0.87 \pm 0.06(42.2)^{\mathrm{c}}$ \\
PM-26 & 50 & day 1-day 5 (i.p.) & $1.02 \pm 0.02$ & $1.11 \pm 0.05(26.5)^{\mathrm{a}}$ \\
PM-32 & 100 & day 1-day 5 (i.p.) & $1.03 \pm 0.01$ & $1.06 \pm 0.04(29.7)^{\mathrm{b}}$ \\
CDDP & 2 & day 1-day 5 (i.p.) & $0.97 \pm 0.03$ & $0.82 \pm 0.03(46.6)^{\mathrm{a}}$ \\
5-FU & 30 & days 1, 4 (i.p.) & $0.99 \pm 0.01$ & $0.85 \pm 0.02(44.0)^{\mathrm{a}}$ \\
MMC & 2 & days 1, 4 (i.p.) & $1.04 \pm 0.01$ & $0.83 \pm 0.02(44.9)^{\mathrm{a}}$ \\
ACNU & 10 & days 1, 4 (i.p.) & $1.01 \pm 0.01$ & $0.94 \pm 0.09(37.6)^{\mathrm{b}}$ \\
ADM & 5 & days 1, 4 (i.p.) & $0.97 \pm 0.02$ & $0.87 \pm 0.02(42.2)^{\mathrm{a}}$ \\
\hline
\end{tabular}

${ }^{1}$ At day 6 after tumor implantation, tumor sizes of mice treated with chemicals were compared to that of vehicle control mice. ${ }^{2} \mathrm{PM}-8,\left[\mathrm{NH}_{3} \mathrm{Pri}\right]_{6}\left[\mathrm{Mo}_{7} \mathrm{O}_{24}\right] \cdot 3 \mathrm{H}_{2} \mathrm{O}$; $\mathrm{PM}-17, \quad\left[\mathrm{NH}_{3} \mathrm{Pri}\right]_{6}\left[\mathrm{HxMo} \mathrm{O}_{24}\right](\mathrm{x}=1-2) ; \mathrm{PM}-26,\left[\mathrm{NH}_{3} \mathrm{Pri}\right]_{6}\left[\mathrm{Mo}_{7} \mathrm{O}_{26}\right] \cdot 3 \mathrm{H}_{2} \mathrm{O} ; \mathrm{PM}-$ $32, \mathrm{Na}_{5}\left[\mathrm{IMo}_{6} \mathrm{O}_{24}\right] \cdot 34 \mathrm{H}_{2} \mathrm{O}$. ${ }^{3} \mathrm{Mean} \pm$ S.E. of five mice. ${ }^{4}$ Values in parentheses indicate $\%$ inhibition of tumor growth. $\quad \mathrm{a}, \mathrm{b}$ and $\mathrm{c}$ indicate significant differences in the values for relative tumor size between vehicle control mice and treated mice $(p<0.02, p<0.01$ and $p<0.001$, respectively). 
TABLE 2. Antitumor effect of PM-8 against human cancer xenografts implanted under the subrenal capsule in mice ${ }^{1}$

\begin{tabular}{clccc}
\hline Tumor & Compound & $\begin{array}{c}\text { Dose } \\
(\mathrm{mg} / \mathrm{kg})\end{array}$ & $\begin{array}{c}\text { Treatment } \\
\text { schedule }\end{array}$ & $\begin{array}{c}\text { Relative tumor size } \\
\text { (day 6/day 0) }\end{array}$ \\
\hline \multirow{2}{*}{ MX-1 } & Tumor control & Vehicle & day 1-day 5 (i.p.) & $1.45 \pm 0.15^{2}$ \\
& PM-8 & 200 & day 1-day 5 (i.p.) & $0.75 \pm 0.14^{\mathrm{a}}$ \\
& & 100 & day 1-day 5 (i.p.) & $0.80 \pm 0.07^{\mathrm{b}}$ \\
& 5-FU & 30 & day 1-day 5 (i.p.) & $0.81 \pm 0.10^{\mathrm{a}}$ \\
OAT & Tumor control & Vehicle & day 1-day 5 (i.p.) & $2.45 \pm 0.25$ \\
& PM-8 & 200 & day 1-day 5 (i.p.) & $1.40 \pm 0.07^{\mathrm{a}}$ \\
& & 100 & day 1-day (i.p.) & $1.55 \pm 0.15^{\mathrm{a}}$ \\
& 5-FU & 30 & day 1-day (i.p.) & $0.65 \pm 0.05^{\mathrm{c}}$ \\
\hline
\end{tabular}

${ }^{1}$ At day 6 after tumor implantation, tumor sizes of mice treated compound were compared to that of vehicle control mice. ${ }^{2}$ Mean \pm s.e. of five mice. $a, b$ and $c$ indicate significant differences between saline control group and treated groups $(p<$ $0.05, p<0.02$ and $p<0.001$, respectively).

5-FU. The doses were $200 \mathrm{mg} / \mathrm{kg}$ and $100 \mathrm{mg} / \mathrm{kg}$ for PM- 8 and $30 \mathrm{mg} / \mathrm{kg}$ for 5-FU. PM-8 exhibited significant antitumor activities against both human cancer xenografts shown in Table 2. Against MX-1, the activity of PM-8 was equal to that of 5 -FU, which showed a T/C value of $51 \%(p<0.05), 54 \%(p<0.02)$ at $200 \mathrm{mg} / \mathrm{kg}$ and $100 \mathrm{mg} / \mathrm{kg}$, respectively, and 5 -FU displayed a $\mathrm{T} / \mathrm{C}$ value of $56 \%$ $(p<0.05)$. On the other hand, against OAT, 5-FU showed significant activity with a T/C value of $9.6 \%(p<0.001)$. The T/C values of PM-8 were $61.9 \%(p<$ $0.05)$ at $200 \mathrm{mg} / \mathrm{kg}$ and $71.6 \%(p<0.05)$ at $100 \mathrm{mg} / \mathrm{kg}$.

TABLE 3. Antitumor effect of $P M-8$ against human cancer xenografts in nude mice ${ }^{1}$

\begin{tabular}{|c|c|c|c|c|c|c|}
\hline \multirow{2}{*}{ Tumor } & \multirow{2}{*}{ Compound } & \multirow{2}{*}{$\begin{array}{l}\text { Dose } \\
(\mathrm{mg} / \mathrm{kg})\end{array}$} & \multirow{2}{*}{$\begin{array}{l}\text { Treatment } \\
\text { schedule }\end{array}$} & \multicolumn{3}{|c|}{$\begin{array}{l}\% \text { of inhibition of } \\
\text { tumor growth at }\end{array}$} \\
\hline & & & & day 10 & day 20 & day 30 \\
\hline \multirow[t]{4}{*}{ MX-1 } & Tumor control & Vehicle & day 1 -day 10 (i.p.) & - & - & - \\
\hline & PM-8 & 200 & day 1-day 10 (i.p.) & $60^{\mathrm{b}}$ & $62^{\mathrm{b}}$ & $70^{\mathrm{d}}$ \\
\hline & & 100 & day 1-day 10 (i.p.) & $50^{\mathrm{a}}$ & $40^{\mathrm{a}}$ & $62^{\mathrm{d}}$ \\
\hline & $5-\mathrm{FU}$ & 30 & days $1,3,5,7,9$ (i.p.) & $80^{c}$ & $80^{\mathrm{d}}$ & $82^{d}$ \\
\hline \multirow[t]{4}{*}{ OAT } & Tumor control & Vehicle & day 1-day 10 (i.p.) & - & - & - \\
\hline & PM-8 & 200 & day 1-day 10 (i.p.) & $70^{\mathrm{a}}$ & $69^{\mathrm{d}}$ & $63^{\mathrm{d}}$ \\
\hline & & 100 & day 1-day 10 (i.p.) & 40 & $50^{\mathrm{a}}$ & $54^{\mathrm{d}}$ \\
\hline & $5-\mathrm{FU}$ & 30 & days $1,3,5,7,9$ (i.p.) & $85^{\mathrm{c}}$ & $77^{\mathrm{c}}$ & $75^{\mathrm{d}}$ \\
\hline
\end{tabular}

${ }^{1}$ Mice were used in groups of five. $a, b, c$ and $d$ indicate significantly differences between saline control group and treated groups $(p<0.05, p<0.02, p<0.01, p<0.001$, respectively). 
Antitumor activities of $P M-8$ against $M X-1$ and $O A T$ in nude mice

The antitumor activities of PM-8 against xenografts implanted in nude mice were investigated. The experimental result was shown in Table 3. PM-8 showed significant antitumor activities against MX-1 and/or OAT human cancer in nude mice.

\section{Discussion}

The antitumor activities of the polyoxometalates were evaluated using a human tumor-nude mouse system and compared with those of antitumor chemotherapeutic drugs. Of polyoxometalates with their structures based on closely packed oxygen arrays containing interstitial metal centers, PM-8, 17, 26 and 32 were found to exhibit antitumor activities against Co- 4 human colon cancer xenograft using SRC assay in mice. Especially, PM-8 was the most active. The geometry of $\left[\mathrm{Mo}_{7} \mathrm{O}_{24}\right]^{6-}$ for $\mathrm{PM}-8$, consisting of seven $\mathrm{MoO}_{6}$ octahedra condenced by edgesharing into the structure is shown in Fig. 1.

It is notable that PM-8 showed antitumor activities against human cancer xenografts. The conventional murine tumor systems have contributed greatly to the development of new antitumor agents, but they are not necessarily clinical effective. Many active compounds in these systems have been clinically inactive. On the other hand, the human tumor-nude mouse systems have been moreuseful for identifing new anticancer agents of clinical interest.

Particularly, it has been reported that the effects of 5-FU, ADR or CDDP against several human tumor exnografts reflect the clinical response rate very closely. They are the most potent antitumor drugs currently available, but their activities are not necessarily sufficient in terms of curative therapy for cancer patients. So more active antitumor agents are still needed.

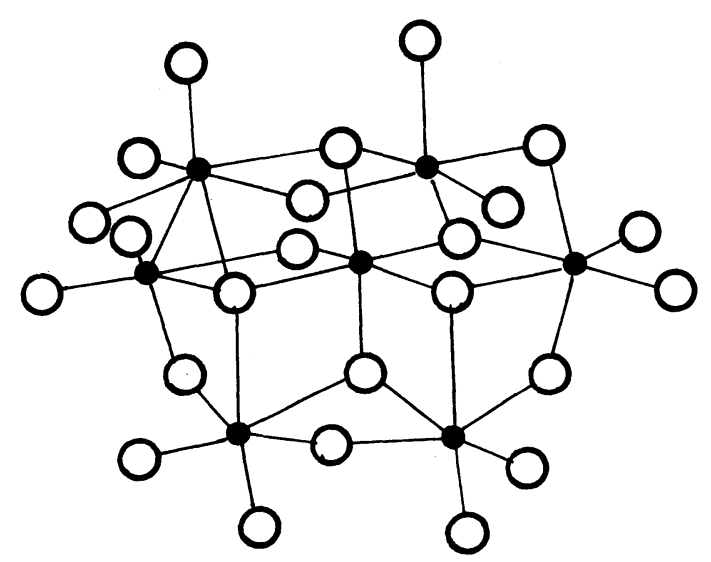

Fig. 1. Structure of $\left[\mathrm{Mo}_{7} \mathrm{O}_{24}\right]^{6-}$. O, oxygen atom; $\bullet$, Mo atom. 
Since PM-8 exhibited significant antitumor activities in human cancer-nude mouse systems, it could be a promising candidate for clinical studies. To study the structure-activity relationship of PM-8, the influence of chemical variation on the murine tumor inhibiting activity was investigated. This modification was made in three different ways : (1) the $\left[\mathrm{NH}_{3} \text { Pri }\right]^{+}$cation was replaced by $\left[\mathrm{NH}_{4}\right]^{+}$ and $\mathrm{K}^{+}$; (2) the $\left[\mathrm{Mo}_{7} \mathrm{O}_{24}\right]^{6-}$ anion was replaced by $\mathrm{Cl}^{-}$; (3) the $\mathrm{d}^{0}$ configuration of a Mo atom in $\left[\mathrm{Mo}_{7} \mathrm{O}_{24}\right]^{6-}$ was changed photochemically to the $\mathrm{d}^{1}$ configuration $\left[\mathrm{H}_{\mathrm{x}} \mathrm{Mo}_{7} \mathrm{O}_{24}\right]^{6-}$.

Antitumor activities of these modified compounds against Meth $\mathrm{A}$ sarcoma were investigated. $\left[\mathrm{NH}_{4}\right]^{6-}\left[\mathrm{Mo}_{7} \mathrm{O}_{24}\right] \cdot 4 \mathrm{H}_{2} \mathrm{O}$ and $\mathrm{K}_{6}\left[\mathrm{Mo}_{7} \mathrm{O}_{24}\right] \cdot 4 \mathrm{H}_{2} \mathrm{O}$ were effective, whereas $\left[\mathrm{NH}_{3} \mathrm{Pri}\right] \mathrm{Cl}$ was ineffective against Meth-A tumor bearing mice. Especially, $\left[\mathrm{NH}_{3} \mathrm{Pri}\right]^{6-}\left[\mathrm{H}_{\mathrm{x}} \mathrm{Mo}_{7} \mathrm{O}_{24}\right]$ exhibited a significant inhibition on the growth of Meth A sarcoma. The results indicate that the polyoxomolybdate structure of the $\mathrm{Mo}_{7} \mathrm{O}_{24}$ is apparently of critical significance for the antitumor activity. The administration of PM-17 caused a severe body weight loss, suggesting that the reduction of PM-8 by up to two electrons results in an adverse effect on the mice as seen in Table 1. The action mechanism on antitumor activity of PM-8 is not yet clear. PM-8 exhibited non specific weak interaction with DNA (Tomita et al. 1989). Thus PM-8 can be distinguished from the antitumor mechanism of a mononuclear metal complex such as CDDP and other organometalic compounds.

\section{References}

1) Fujita, H., Fukushima, K., Sakurai, T., Fukuma, M., Seto, Y., Fujita, T., Itoh, K., Shinohara, N., Yamamoto, Y. \& Ishihara, T. (1990) Biological activity of organosilicone compounds - Study on cancer chemotherapeutic activity - . J. Chem. Industri. Chem., 5, 566-574.

2) Harstrick, A., Casper, J., Guba, G., Wilke, H., Poliwoda, H. \& Schmoll, H. (1983) Comparison of the antitumor activity of cisplatin, carboplatin and iproplatin against established human testicular cancer cell lines in vivo and in vitro. Cancer, 63, 10791083.

3) Rosenberg, B., Van Camp, B.J., Trosko, J.E. \& Mansour, V.H. (1969) Platinum compounds ; A nes class of potent antitumor agents. Nature, 222, 385-386.

4) Sakurai, T. (1990) Antimetastatic effects of organic silicone compounds in mice bearing lewis lung carcinoma. Chemotherapy, 38, 879-888.

5) Samson, M.K., Rivkin, S.E., Jones, S.E., Costanzi, J.J., Lobugglio, A.F., StEphens, R.L., Gehans, E.A. \& Cummings, M.D. (1984) Dose-response and dose-survival advantage for high versus low-dose cisplatin compounds with vinblastin and bleomycin in disseminated testicular cancer. Cancer, 53, 1029-1035.

6) Tomita, K., Yamase, T. \& Shishido, K. (1989) Medical chemistry of polyoxometalates Part 2. Enzymatic study on binding of heptamolybdate to DNA. Inorg. Chim. Acta, 157, 167-169.

7) Toyoshima, S., Fujita, H., Fukushima, K., Sakurai, T. \& Seto, Y. (1985) A new potent antitumor agent, organic silicone compounds. Recent Adv. Cancer Chemother., 1, 945-946.

8) Yamase, T., Fujita, H. \& Fukushima, K. (1988) Medical chemistry of polyox- 
ometalates Part 1. Potent antitumor activity of polyoxomolybdates on animal transplantable tumors and human cancer xenografts. Inorg. Chim. Acta, 151, 15-18. 